\title{
Progressive and Reactionary Rhetoric in the Municipal Reform Debate in New South Wales (NSW) Australia
}

ABSTRACT: Hirschman's (1991) rhetoric of reaction is a potentially powerful typology of the arguments made by both proponents and opponents of reform. However, scholars have identified a number of gaps in the typology, in particular that it has struggled to explain the lines of rhetoric associated with disputed empirical evidence. This paper reviews Hirschman's typology before applying it to the contentious municipal amalgamation debates currently unfolding in New South Wales, Australia. We then examine the lines of attack open to progressives and reactionaries on the basis of empirical data. We conclude that the use of empirical data opens new lines of rhetoric for both 'progressives' and 'reactionaries' generally, but that both information costs and complexity significantly affect the timing and penetration of the arguments.

Keywords: Municipal reforms; NSW state government; rhetoric of reaction; silence; Sydney global city. 


\section{Introduction}

In The Rhetoric of Reaction Albert Hirschman (1991) established a typology of the major polemical manoeuvres employed by the proponents and opponents of public policy reforms. Hirschman (1991: x) examined the 'imperatives of arguments' that shape discourse 'almost regardless of the desires, character, or convictions of the participants'. If it is indeed true that public policy reform debates 'lumber ... predictably through set motions and manoeuvres' (Hirschman in Adelman 2013: 308), then knowledge of the means of persuasion must be considered a delectably powerful tool for rhetors as well as the 'citizens who, in the end, are the ones who must make all judgements' (Finlayson 2006: 556). Thus, the potential rewards of proving and improving on the utility of Hirschman's (1991) typology warrant careful scholarly attention, including testing the typology in a range of contexts.

It is important to understand Hirschman's (1991) conception of rhetoric in order to appreciate the purpose of his typology. Colloquially, rhetoric is associated with discourse devoid of meaning, often employed to deceive listeners regarding an agent's true intentions (McCloskey 1998). However, the Aristotelian (2012: 8) conception of rhetoric views it as an art; 'the faculty of defining in any given case the available means of persuasion'. Finlayson (2006: 544) has written extensively employing a broad Aristotelian conception of rhetoric as a 'creative activity in which a political actor seeks to develop arguments and put them to an audience in a way that they will be encouraged to pursue a particular course of action'. There is also an impressive strand of Australian scholarship concerned with political rhetoric, analysing the use of metaphor in justifying public policy (Roan and White 2010); studying linguistic phenomena in 'compet[ing] for control of normative force that derives from applying descriptions' of salient terms (Walter and Uhr 2013: 432); examining the paradox of democratic rhetoric that obliges leaders to employ a style that sounds un-rhetorical (Kane and 
Patapan 2010); and considering constraints that the electoral cycle places on the 'rhetorical framework for election defining speeches' (Grube 2011: 48). In contrast, Hirschman's (1991) conception of rhetoric is rather narrow, largely neglecting the ethos and the pathos in favour of a detailed account of the logos: Aristotelian rhetoric stripped bare of art.

Hirschman's (1991) typology seeks to contrast the rhetorical devices of 'progressives' against those of 'reactionaries' and he went to some lengths to clarify what he meant by these terms. Thus: '[M]y aim is to delineate formal types of argument or rhetoric' (Hirschman 1991: 6). Further: 'I am not going to embark on a broad and leisurely historical retelling of the successive reforms and counterreforms, theses and countertheses, since the French Revolution. Instead, I shall focus on a few common or typical arguments unfailingly made by each [side]' (Hirschman 1991: 6-7). Moreover, Hirschman (1991: 8) associated the term 'reaction' with Newton's third law of motion and sought to use the terms 'progressive' and 'reactionary' in what we will label as a Newtonian rather than an ideational sense. Otherwise stated, for Hirschman (1991) 'progressives' are simply those who seek to implement reform, whilst 'reactionaries' are those who resist reform.

Despite his efforts in this regard, Hirschman's work has been subject to three principal criticisms. First, it has been interpreted as an 'anti-neo-conservative manifesto' focussed on exposing conservative polemical manoeuvres (see, for example, Hirschman 1993: 303). That the bulk of Hirschman's (1991) book examines reactionary rhetoric has been used as 'evidence' of its 'left-wing' bias, with the single chapter on progressive rhetoric being dismissed as a base attempt to establish impartiality (Hirschman 1993: 303). Indeed, Hirschman (1993: 303) admitted that the motivation for his book was 'a sense of anger over the neo-conservative offensive' under Ronald Reagan, but argues that the chapter on 
progressive rhetoric was a providential and unintended consequence of his scholarly integrity. Yet despite his strident protestations, the Rhetoric of Reaction continues to attract criticism for identifying reactionaries with the political Right (see, for instance, Shorten 2015). Notwithstanding the complexities of political ideology in any one context or, indeed, more generally, in the ensuing discussion we test the claim that the typology is an 'anti-neoconservative manifesto' by employing it in the Australian context, where a Liberal-National Party government is cast as the 'progressives'.

A second criticism of Hirschman's (1991) typology has been that it fails to 'accommodate debate involving disputed empirical evidence' (Burton, Dollery and Wallis 2002; Dollery and Crase 2003). Given that many public policy debates centre on empirical claims, a deficiency of this sort would impose major constraints on the typology. In this context we test this assertion and propose amendments to correct the deficiencies identified.

Third, it has been claimed that Hirschman's (1991) typology has been 'attacked by various scholars' on the basis that a dichotomous typology is "not rich enough to capture the complexities of the rhetorical arguments surrounding fundamental policy reforms' (Hood cited by Dollery and Crase 2010: 358). However, this claim appears to be a misrepresentation of Hood's (1998: 185) work, given that the criticism was in fact levelled at Hirschman's 'claim about the special hold conservatives have on irony' not his dichotomous representation of rhetorical manoeuvres. Indeed Hood (2007) employed Hirschman's work in later scholarly outputs. Nevertheless, we argue that Hirschman's (1991) typology, despite its formalism, was only ever intended to outline the major polemical manoeuvres employed in public policy rhetoric; indeed Hirschman (1991, p. 134) stated clearly that 'it would no doubt be foolhardy on my part to claim exhaustiveness'. This admission - and the extensive use of historical 
examples in The Rhetoric of Reaction - clearly implies that Hirschman (1991) is attuned to the embedded and, in some instances, cyclical nature of public policy debates ${ }^{1}$.

Both our defence and extension of Hirschman's (1991) typology are fleshed out in the ensuing discussion. The particular field of public policy that the paper examines in this regard is local government reform in NSW. Since 2012, and echoing previous iterations of the same public policy question both in NSW and elsewhere in Australia (Dollery and Tiley 2015; LGI 2006), NSW has been embroiled in a vigorous debate regarding whether up to 40 per cent of the state's 152 councils should be amalgamated in order to improve the strategic capacity and financial sustainability of the local government sector. The amalgamation debate was initiated by the Independent Local Government Review Panel (ILGRP), a three-member body commissioned by the (then) state Minister for Local Government in August 2011 to 'draw on independent expertise' to 'identify how councils can best govern and be structured to support the future wellbeing and prosperity of NSW communities' (Destination 2036 2012: 4). In 2012 the panel issued the first of three reports in which it presented 'a case to consider significant consolidation of local government across the Sydney metropolitan area, and in other major urban regions, and some regional centres' (ILGRP 2012: 5). This argument for municipal consolidation was developed into a series of 'merger recommendations' and presented to the state government in October 2013 in the ILGRP's 'Final Report', with the injunction that "sooner or later amalgamations will have to be part of the package: the number of councils in NSW has halved during the past century and that trend will surely continue' (ILGRP 2013a: 7).

\footnotetext{
${ }^{1}$ The authors would like to thank an anonymous Reviewer for highlighting this point.
} 
In response to the panel's 'Final Report' the NSW Government launched the 'Fit for the Future' program, which required councils with 'insufficient scale and capacity' to develop a council merger proposal according to templates provided by government. These templates gave primacy to seven financial ratios, and councils were advised that judgements on adequate scale and capacity would be based on the 'merger recommendations' made by the ILGRP (2013b). The Independent Pricing and Regulatory Tribunal (IPART) was commissioned by the government to provide 'independent' 'expert' assessments of the council proposals, released on 16 October, 2015; wherein IPART emphasised that 'any final decision related to the implications of our advice is a matter for the Government' (IPART 2015: 14).

On 18 December 2015 the Baird government announced plans to create ' 15 new, stronger councils' in the Sydney Metropolitan Region (SMR), thus reducing the number of metropolitan councils from 43 to 25 , with a concurrent reduction in non-metropolitan councils from 109 to 87 (Baird 2015). Much remains to be done to execute this policy (Baird 2015). Nevertheless the reform program presents a valuable opportunity to test Hirschman's (1991) typology of rhetoric in the crucible of a contemporary and contentious public policy debate.

Reverting to Hirschman's (1991) typology, two parties can be identified in the debate, each of which has sought to persuade the community of opposing views on amalgamation. In the 'progressives' corner, the NSW Premier and the Minister for Local Government have both argued strongly for their belief that councils must amalgamate because inter alia 'the people of NSW deserve a great place to live - a strong economy, quality services and a bright and prosperous future' (OLG 2014: 4). The minister has also asserted on a number of occasions 
statements to the effect that: [W]e cannot continue as we have done in the past. Councils are losing \$1 million a day and it is not the way of the future (Hansard 2014b: 399).

Facing off against the 'progressives' is a diverse group, comprising some academics, opposition politicians, media personalities and councillors, who have adopted various 'reactionary' arguments: For example, that forced amalgamation will result in diminished democratic representation; the proposed amalgamations will result in oversized councils with concomitant diseconomies of scale; the reforms are a smokescreen for a political agenda designed to push through development proposals against community wishes or to gerrymander the state in favour of the Liberal Party (see, for example, Drew, Kortt and Dollery 2015; Foley 2015; Jones 2015; Silmalis 2015).

The following section outlines the progressive rhetoric employed to prosecute the case for public policy reform and considers arguments used in the NSW municipal amalgamation debate. Next, we consider the major strands of reactionary rhetoric used to resist public policy change and, once again, we make recourse to a number of artefacts drawn from the 'Fit for the Future' discourse. We then address the claim that the Hirschman (1991) typology cannot completely accommodate debates based on disputed empirical evidence by considering empirical claims advanced by the progressives and reactionaries. We conclude with a summary of the utility of Hirschman's (1991) typology, suggestions for improvements, and recommendations for further research.

\section{Progressive rhetoric in the NSW municipal amalgamation debate}

Hirschman's (1991) review of historical public policy debates yielded three lines of progressive rhetoric employed by proponents of change: (i) the Imminent Danger thesis and 
Synergistic fallacy, (ii) the Desperate Predicament thesis and Fracasomania and (iii) the Futility of Resistance thesis. First, the Imminent Danger thesis emphasises the perils of passivity and urges action to be taken to forestall looming threats. Further, progressives employing this argument generally appeal to the principle of synergy (the idea that the proposed reforms will neatly complement previous work). Thus, progressives pursuing this argument are endowed with extraordinary levels of confidence: confidence that their predictions of looming danger are correct and confidence that proposed reforms will positively contribute to previous efforts and that no undesirable interaction effects will result (Hirschman 1991: 153).

The Imminent Danger thesis has been a comparatively muted line of progressive rhetoric in the 'Fit for the Future' debate. Nevertheless, the NSW Government literature produced to promote the reform program alludes to looming threats: 'Sydney is the fastest growing capital city in Australia ... To cope with this growth and Sydney's emerging role as a Global City, we need a modern, more connected system of local government (OLG 2014: 8). The Imminent Danger argument was also prosecuted by the Minister for Local Government in Parliament when he stated thàt:

\footnotetext{
In the next 20 years a further two million people will make the city their home, and most of them will settle in Sydney's west ... To cope with this growth and Sydney's emerging role as a global city, we need a modern, more connected system of government' (Hansard 2015a: 3).
}

Much more prominent has been the Synergistic principle that Hirschman (1991) associated with the Imminent Danger thesis. However, in this case the synergy claim is made in relation 
to future reforms rather than previous efforts. For instance, the government literature nominates a number of planned reforms, including reductions to 'red tape', the establishment of a central auditor and two-year terms for mayors (previously one year), which it states will 'help councils become fit for the future' (OLG 2014: 13). This forward-looking synergy claim is an unusual method of complementing the Imminent Danger thesis and does not appear to be a permutation considered by Hirschman (1991). However, linking the 'Fit for the Future' reforms to future policy changes does help to support the Imminent Danger thesis the implication being that the looming threats are so great that a series of policy changes will be required to mitigate same.

Second, the Desperate Predicament thesis was undoubtedly the most conspicuous form of progressive rhetoric employed by the government. Put simply, this line of argument seeks to paint a picture of a state of affairs so dire as to require authorities to dispense with all caution and take immediate action, irrespective of potential unintended consequences. As such it is a clarion call to arms. A related argument sometimes employed by progressives invoking the Desperate Predicament thesis is what Hirschman (1991) referred to as the Fracasomania claim: The idea that because all previous attempts to improve the situation have failed it is no longer reasonable to expect that improvement through gradual change is possible. The Desperate Predicament thesis has been an outstanding feature of the rhetoric surrounding 'Fit for the Future' from the outset. For instance, the ILGRP (2013b: 4) employed the thesis in its penultimate report, noting that: '[T]he recently released report of the NSW Treasury Corporation (TCorp) paints a disturbing picture of a local government system facing major financial problems with apparently little awareness of just how serious the situation has become. 
The state government also put considerable effort into prosecuting the case for reform on the basis of the Desperate Predicament thesis. Thus, the claim made to Parliament on 11 September 2014 (cited in the Introduction) was preceded by a similar statement the previous day: 'this is an incredible $\$ 1$ million daily loss for local councils.... this cannot be sustained' (Hansard 2014a). On 2 June 2015 the minister returned to the Desperate Predicament thesis in Parliament, stating that ' Labor $^{2}$ left a system that was in tatters, falling apart, in ruins ... councils cannot continue to lose up to \$1 million a day' (Hansard, 2015b: 1202). This statement was reinforced through a media release entitled 'Report card shows majority of councils still operating in the red' (Toole 2015). This media release was picked up by the national broadcaster in a report which (incorrectly) stated: '101 out of 152 councils were in deficit in 2013-14 which was 13 more than the previous year' (Brown 2015) ${ }^{3}$. Relatively little effort was put into the Fracasomania argument, although several references to the fact that the NSW Government had 'been working with councils since 2011 to achieve our shared vision of strengthening local communities' may be found in the supporting literature (OLG 2014).

The third progressive line of rhetoric in Hirschman's (1991) typology is the Futility of Resistance argument. Arguments of this type draw on a belief regarding the inevitable direction of historical progress, resistance to which is pointless, or alternatively an inevitable feature of human society that cannot be altered and against which it is futile to argue. Historically, arguments of this type have been associated with one or more 'laws' identified by philosophers or social scientists. Hirschman (1991: 57) cited the 'Iron Law of Oligarchy' developed by Roberto Michels in his Political Parties. Further, the idea that 'newer is better'

\footnotetext{
${ }^{2}$ The NSW Labor Party held government for 16 years up until March, 2011.

${ }^{3}$ The media release claimed that just 41 councils reported a surplus for the year. First, there is a serious question on the validity of the government's accounting 'facts' (see 'A Focus on Empirical Rhetoric' below). Second, there are 152 councils in NSW: Thus arithmetic suggests that the ABC should have reported 111 councils in deficit.
} 
pervades much of western contemporary thought, suggesting that it is likely to be an argument of great penetration (Hirschman, 1991).

The NSW Government employed this argument in the promotional material for 'Fit for the Future', claiming that change was necessary because 'many of our growing suburbs are constrained by boundaries that date back to the horse and cart days' (OLG 2014: 4). In a similar vein, the Minister for Local Government declared in Parliament that "we are dealing with an out-of-date system that is more than 100 years old with boundaries that were drawn up more than 100 years ago [sic] back in the horse-and-cart days' (Hansard 2014a: 239). On the next day the minister declared that 'this commitment has been given by the Premier and the members of this side of the House to ensure we support local government to modernise for the future' (Hansard 2014b: 399). Finally, as noted in the introduction, the ILGRP also invoked the futility of resistance argument when it asserted that 'the number of councils in NSW has halved during the past century and that trend will surely continue' (ILGRP 2013a: 7).

In summary, the Desperate Predicament and Futility of Resistance theses have been the favoured progressive rhetorical devices employed by the state government architects of the NSW municipal reforms. Further, it seems that the politicians involved believed that these arguments were compelling reasons for change, given that the rhetorical devices were repeatedly used throughout the long debate over forced local government amalgamations. We now turn to the reactionary rhetoric employed to counter the progressive's various claims. 


\section{Reactionary rhetoric in the New South Wales municipal amalgamation debate}

Hirschman (1991) posited that each of the 'progressive' lines of rhetoric has a countervailing 'reactionary' argument: The Imminent Danger thesis finds its counterpart in the Jeopardy thesis, that the Desperate Predicament thesis is opposed by the Perversity thesis and the Futility of Resistance thesis is parried by the Futility thesis. Hirschman (in Adelman 2013: 296) stated that 'because of the stubbornly progressive temper of the modern era, reactionaries live in a hostile world' and are therefore not in the position to launch an all-out attack on the policy reform objectives. 'Rather they will endorse them, sincerely or otherwise, but then attempt to demonstrate that the actions undertaken in their name are ill conceived' and will result in a number of unacceptable outcomes (Adelman 2013: 296). In the case of 'Fit for the Future' this would imply that reactionaries would endorse the objective of 'strong councils providing the services and infrastructure communities need' (OLG 2014: 2) but challenge some of the outcomes that may arise.

Examining the reactionary rhetoric in turn, using the Jeopardy thesis, reactionaries typically argue that the 'proposed change, though perhaps desirable in itself, involves unacceptable costs or consequences of one sort or another' (Hirschman 1991: 81). Unlike the other reactionary rhetoric, jeopardy arguments can easily accommodate value-based polemics. For instance, The Daily Telegraph led with the story 'All NSW councils to be sacked before forced move to "super council”, Minister proposes' (Silmalis 2015), with a colour graphic illustrating the dilution of democratic representation under the proposed amalgamation plan for the North Sydney group of councils (under Section 224(1) of the Local Government Act (1993) the existing 61 political representatives can only be replaced with a maximum of 15 representatives). This 'dilution of democracy' argument was also picked up by television news media (Ten News 2015). Further, the state opposition (Labor) and other stakeholders 
have argued that amalgamations should proceed only after successful referenda on the matter and to do otherwise would represent an 'assault on democracy' (McKenny 2015; see also Save our Councils Coalition 2015). Thus, the argument employed by reactionaries against 'Fit for the Future' is that it is unacceptable to dispense with cherished democratic values, even in the face of the threat that local government may not be able to contribute to 'a strong economy and a bright and prosperous future' (OLG 2014: 4).

Second, Hirschman (1991: 140) noted that the Perversity thesis is 'the single and most popular and effective weapon in in the annals of reactionary rhetoric'. This claim has been validated in other scholarly papers that have applied the Hirschman (1991) typology to contentious public policy debates (see, for instance, Burton et al. 2002). This is also the case in the 'Fit for the Future' debates. The Perversity thesis is/a consequentialist argument that has its foundation in the belief that actions intended to produce one state of affairs can result in an entirely unintended state of affairs. Unintended outcomes are prominent in economics (for instance, Adam Smith's invisible hand) and moral theory (for example, Aquinas's Principle of Double Effect; see Drew, Grant and Fisher, forthcoming). It is therefore unsurprising that arguments of this type will penetrate public policy debates. Moreover, as pointed out by Hood (1998) the Perversity thesis plays directly to the powerful rhetorical trope of irony - asserting that actions designed to improve the 'desperate predicament' will actually make matters worse.

One example of the Perversity thesis applied to the NSW forced municipal amalgamation debate is the scholarly work of Drew et al. (2015). The article employed Data Envelopment Analysis (DEA) to empirically estimate the scale and efficiency of NSW councils on the basis of the ILGRP (2013b) merger recommendations. The analysis found that 'of the 23 
recommended amalgamation groups (formed from 63 existing councils), 20 will initially result in DRS [decreasing returns to scale] entities, with a mere two proposed entities exhibiting optimal scale and one recommended entity displaying IRS [increasing returns to scale]' (Drew et al. 2015: 17). This perverse outcome was highlighted by the United Services Union (USU) and several councils in their submissions to the Independent Pricing and Regulatory Tribunal (IPART) charged with determining municipal 'fitness' (see, for instance, City of Ryde 2015; USU 2015). Remarkably, the media largely neglected this empirical evidence in particular and the perversity argument in general (see 'A Focus on Empirical Rhetoric' (below) for reasons why the scholarly work failed to gain traction in the popular media).

However, the political opposition did employ the Perversity thesis in their resistance to the reforms. For example, the, Shadow Minister for Local Government, (Hansard 2015c: 92) made reference to extant empirical analysis in parliamentary debate, noting that: 'He [the Minister for Local Government] threatens forced amalgamations but never provides the empirical evidence to show - contrary to the academic research - that bigger is better'. Moreover, Alex Greenwich, Independent member for Sydney, summarised the Perversity thesis in his motion to Parliament opposing forced amalgamations:

Bigger councils will not necessarily improve efficiencies. Economies of scale do not always work. Large organisations need more administration and management resources, and larger bureaucracies can be less efficient ... Mergers have short-term costs and disruptions as councils combine staff, planning controls, rating categories, services and information technology systems. Conflicts between different work cultures can reduce productivity ... 
There are real risks that financially strong councils could become less sustainable if they merge with weaker ones (Hansard 2015a: 1).

In the ensuing debate the amended motion was defeated (38/47) by the Coalition majority (Hansard 2015a).

The third type of reactionary rhetoric identified by Hirschman (1991) was the Futility thesis. Like the Perversity thesis, this argument is a consequentialist determination founded on the idea of unintended consequences. However, the Futility thesis does not predict outcomes opposite to intended objectives; rather, reactionaries employing this rhetorical device simply assert that the proposed policy will have no effect on the identified aim. Hirschman (1991) was clear that this should not be considered a weakened form of the Perversity thesis for several reasons. For a start, the two theses are motivated by very different world views; the Futility rhetoric is prompted by a belief in a structured world which is changing (or not) according to inviolable laws, whereas those who employ the Perversity thesis consider the world to be unpredictable and even chaotic (Hirschman 1991). Further, the motivations likely to be attributed to the architects of the disputed public policy differ. According to the Futility mindset, the architects of reform are seeking to change the unchangeable, providing scope for suspicion regarding the intention of the proponents of reform. Alternatively, under a Perversity world-view, it is most likely that the architects of reform are innocent 'naïve dogooders [who] fell flat on their face' (Adelman 2013: 302). After all, the Perversity mindset sees the world as unpredictable, therefore making the unintended outcome incredibly likely from a probabilistic perspective and suggesting little cause for blame to be attached to predicted outcomes. 
Several attacks on 'Fit for the Future' were made using Futility rhetoric. For instance, a number of scholars produced analyses suggesting that the amalgamations would not increase financial sustainability (Abelson and Joyeux 2015). In addition, one of Australia's most prominent talk-back radio hosts, Alan Jones (2015), cited research by Drew and Dollery (2014) indicating that amalgamation would not enhance financial sustainability, before raising suspicion that the amalgamations were motivated by a desire to help developers push through development applications against community opinion.

Thus far the arguments employed by both progressives and reactionaries have fitted into the Hirschman (1991) typology, suggesting that policy debates do indeed 'lumber predictably through their paces' (Adelman 2013: 308). The principal arguments advanced by the 'progressives' centred on the dire financial predicament of NSW councils (Desperate Predicament thesis) and the need for changes to cope with future growth needs (Imminent Danger thesis). These 'progressive' thrusts were parried by empirical assessments predicting outcomes opposite to those desired by the architects of reform (Perversity thesis) and arguments condemning 'Fit for the Future' as an assault on democratic values (Jeopardy thesis). Moreover, our analysis has shown that the Rhetoric of Reaction typology can neatly accommodate empirical evidence (in fact empirical evidence was the centrepiece of the Desperate Predicament and Perversity rhetoric concerning 'Fit for the Future'). However, it appears that the use of empirical arguments can open up new avenues of rhetoric for opposing parties in public policy debates. We now borrow from the methodology of Hirschman (1991) and proceed with a close examination of the empirical rhetoric employed in the 'Fit for the Future' debates in order that we might explicate matters.

\section{A focus on empirical rhetoric}


The claim that councils were losing '\$1 million a day' (Hansard 2014b: 339) was the basis of the government's opening salvo in 'Fit for the Future' - a classical Hirschmanesque (1991) Desperate Predicament thesis. The magnitude of this 'fact' is indeed incredible and it may well have been the reason why the government felt secure in launching a politically sensitive reform a mere seven months prior to going to the polls. In response, the reactionaries executed a predictable counter-attack in the form of a Perversity argument led by Drew et al. (2015) in a scholarly paper employing Data Envelopment Analysis (DEA). There is no public record of the government ever engaging with the Perversity claim advanced by Drew et al. (2015) and subsequently highlighted by the United Services Union (2015), several councils (see, for instance City of Ryde 2015) and the political opposition. This then presents us with an example of one powerful alternative response to empirical rhetoric: Silence.

It is true that silence could simply be the result of decision-makers failing to understand empirical arguments ${ }^{4}$. However, silence is also a disarmingly simple but effective response to empirically sophisticated rhetoric. The point here is that we ought to recognise that complex empirical estimations may have little penetration in debates: Few have the skills to engage in debate regarding the techniques employed and it is very difficult for the popular media to fit techniques (such as DEA) into 'soundbites' or 'news headlines' (Kane and Patapan, 2010). Refusing to engage in a debate over the empirical analysis meant that the matter would remain largely in the scholarly literature, thereby posing little threat to public opinion regarding the need for forced municipal amalgamations. Indeed, the government continued to prosecute the case for reform largely on the basis of the Desperate Predicament thesis (see, for instance, 'Report card shows majority of councils still operating in the red' issued on 16 June 2015 (Toole 2015)), although it did alter the format for presenting the thesis somewhat.

\footnotetext{
${ }^{4}$ The authors thank an anonymous Reviewer for alerting us to this possibility.
} 
Further, it is clear that there is a second potential response to a Desperate Predicament thesis founded on empirical accounting 'facts': refutation. This possibility is in addition to the Hirschman (1991) rhetoric of Perversity and emerges because accounting creates 'quite particular objectifications of the otherwise vague and abstract, and particular conceptions of economic facts' according to a complex and highly specialised craft (Hopwood 1987: 229). As a result, the accounting 'facts' deployed by the government as proof of the Desperate Predicament were, to deploy McCloskey’s (1998: 492) observation: '[L]ike other kinds of truth ... fallible and corrigible'. Moreover, with complexity comes high information costs first, as a consequence of the knowledge required to actively engage in a debate on the accounting facts put forward by the government (particularly under accrual based accounting standards) and, second, as a consequence of the enormous quantity of information which would need to be digested in order to determine the validity of the million-dollars-a-day claim (OLG 2015a).

It is thus no surprise that almost ten months elapsed before a coherent refutation was put forward to counter the Desperate Predicament thesis deployed by the Minister of Local Government. On 30 June 2015 the story broke in the Sydney Morning Herald - 'State's councils rich and getting richer as merger deadline looms' - suggesting that, far from losing $\$ 1$ million a day, councils had in fact increased portfolios by 'more than $\$ 1.3$ million a day' (Buckingham-Jones and Robertson, 2015). According to the story, the state government arrived at the figure of losses of an 'incredible million dollars daily' by (i) excluding all contributions and intergovernmental grants obtained for capital purposes ${ }^{5}$ (about 12.6 per

\footnotetext{
${ }^{5}$ The Office of Local Government Accounting Guidelines (2015: 52) does not define 'capital grants' but does state that 'grants and contributions are to be classified as operating or capital depending on the purpose for which they were received and not on the purpose for which they were spent'.
} 
cent of municipal income in 2013) and then (ii) excluding all councils which continued to have a surplus despite the omitted income item (54 of the 152 councils in the 2013 financial year, on which the minister first based his assertion) (Buckingham-Jones and Robertson 2015).

Under an accruals accounting system the costs of purchasing and constructing non-current assets is allocated as a depreciation expense according to Australian Accounting Standard AASB116 (compliant with IAS16) (AASB 2009). The government made no adjustment to the depreciation accrual items when calculating the daily loss incurred by councils. Thus, the procedure adopted by the NSW Government excludes an item of income without matching this to the appropriate expense item, violating a basic principle of double entry accounting. This practice was specifically discouraged in the PricewaterhouseCoopers (PwC 2006: 6) report, National Financial Sustainability Study of Local Government. Moreover, the state government does not exclude grants and contributions for capital purposes from its own budget statements (see, for instance, NSW Government 2014).

By now we imagine most readers have long since stifled a yawn and questioned why they are being assaulted with an accrual accounting lecture - and, in one sense, this is entirely the point. Arguments regarding apparent distortions of accounting facts have little penetration in the popular media. Notwithstanding the report by The Sydney Morning Herald (BuckinghamJones and Robertson 2015), the story gained little traction in the public debate, despite the fact that one could argue that the Minister for Local Government had misled Parliament on a number of occasions and that the Premier himself may have misled the community. It probably should have been a story with significant political repercussions - but instead it remains a largely neglected footnote to a contentious public policy debate. 
Thus we can conclude that refutation is a potential alternative reactionary response to progressive claims based on empirical data (omitted by Hirschman 1991). However, the inherent complexity of this refutation response means it is likely to gain little traction in public policy debate and it appears that an effective response to the counter-attack on the progressive empirical facts is, once again, silence. In this particular case we can be sure that the 'progressives' understood the argument, given that it is fundamental accounting concept. They simply chose to ignore it: In the time since the story was published on 30 June 2015 the minister has avoided comment on the matter and notably has not issued a single media release based upon the Desperate Predicament thesis (see OLG 2015b).

If we conceive of rhetoric in the narrow sense of Aristotelian logos stripped bare of art, then it is debatable whether silence can fit neatly into Hirschman's (1991) typology. However, a broader understanding of rhetoric in terms of the "faculty of defining in any given sense the available means of persuasion' (Aristotle 2012: 8) would accommodate silence as a powerful tool for rhetors and an important interpretive lens for 'citizens who, in the end, are the ones who must make all judgements' (Finlayson 2004: 540). As such, silence should be considered as an integral addendum to Hirschman's typology.

\section{Conclusion}

Our discussion demonstrates that the Hirschman (1991) typology offers significant utility for rhetors, scholars and citizens alike. Hirschman (1991) suggested that the typology is most powerfully employed ex ante by rhetors preparing to persuade citizens on the merits or dangers of a specific public policy reform. However, our analysis highlights an important ex tempore use for the typology that appears to have been overlooked in the literature. In 
particular, the typology can be used by citizens as a lens through which to view debate on disputatious public policy. For instance, knowledge that 'silence' might be employed as a rhetorical foil to important empirical arguments might encourage citizens to demand answers to apparent refutation of empirical 'facts'. In addition, we affirm the utility of Hirschman's (1991) typology as an ex post tool for scholars to analyse public policy debates.

Our analysis has also exposed some limitations in the extant typology which must be addressed if rhetors, citizens and scholars are to gain maximum utility from the tool. This affirms the importance of testing the typology in a range of public policy contexts. In so doing, Hirschman's (1991) seminal contribution can be refined and extended, thereby enhancing its utility. For instance, our analysis has identified that the Synergy claim can be effectively deployed in a forward-looking manner. This observation opens up new possibilities for ex-ante applications by rhetors. However, the most important contribution of this paper is its exploration of empirical rhetoric.

The use of empirical data in public policy debates introduces two important constraints with a direct bearing on the lines of rhetoric which might be employed by both 'progressives' and 'reactionaries'. The first constraint - the complexity of many empirical arguments - may make it difficult for such arguments to gain traction in the media and offers the possibility of alternative conceptions of economic 'facts'. For instance, the government was able to exploit alternative definitions of revenue to present a prima facie persuasive Desperate Predicament argument. Further, the complexity of accrual accounting means that few citizens have the requisite skills to fully understand the 'facts' and may have accepted same without critical analysis. The second constraint relates to the often high information costs associated with 
investigating the validity of empirical claims. Not only does it discourage critical analysis of empirical claims, it also introduces an unavoidable temporal element to empirical rhetoric.

Our analysis has established that empirical data open up new lines of rhetoric for both 'progressives' and 'reactionaries'. One alternative line is for 'reactionaries' to dispute the 'facts'. However, this option is tempered by the constraints of complexity and information cost, so that the response takes some time to formulate and may gain little traction in the media - which, after all, is the principal medium for persuasion (Kane and Patapan 2010). Should 'reactionaries' successfully formulate a refutation then our analysis suggests that 'silence' can be an extremely effective response - particularly in the case of sophisticated empirical analysis. It is also possible that 'silence' may be the default position of decisionmakers failing to understand empirical arguments. Yet the fact that the rhetorical strategy was also employed in the case of the million-dollars-a-day refutation suggests that it was a deliberate rhetorical device in at least this instance. Moreover, even as a default strategy it is clear that 'silence' can limit the persuasive influence of empirical argument.

A number of lessons stem from our analysis of empirical rhetoric. In the first instance, the power and deliberate deployment of 'silence' suggests that Hirschman's (1991) narrow conception of rhetoric is unsatisfactory. At a minimum the conception of rhetoric needs to be broadened to include all forms of persuasion in public policy debates and to recognise the embedded nature of public policy discourse and what is at times its cyclical or, less charitably, its repetitive nature. Second, it alerts the media and citizens that failure to pursue rhetors employing 'silence' in fact confers persuasive power to those seeking to propose or oppose public policy. Moreover, the use of 'silence' should also alert technically qualified 
persons (academics, accountants, lawyers, for example) to the need to present empirical arguments in a manner which is accessible, should they wish to influence public policy.

Third, it is clear that Hirschman's (1991) typology needs to be amended to include forwardlooking Synergy and refutation theses. Finally, the foregoing analysis reveals a deficiency in the scholarly literature with respect to the study of empirical rhetoric in a civic context. Future research should address the use of empirical rhetoric in prosecuting reactionary Jeopardy and Futility theses. There is also scope to investigate the use of empirical accounting 'facts' for persuading citizens of the need for public policy reform, along with considering the role for education in ensuring citizens make informed decisions on public policy matters.

Thus it can be seen that this analysis of the Rhetoric of Reaction has done more than expose the set motions and manoeuvres of public policy debate - it has also explicated on the timing and strategy of empirically laden rhetoric. In so doing, we share with Hirschman (1991) a hope that our work may, in some small way, help to improve the quality of political discourse. 


\section{References}

AASB [Australian Accounting Standards Board]. 2009. AASB116 property, plant and equipment: Compiled accounting standard. Melbourne: AASB. URL: <http://www.aasb.gov.au/admin/file/content105/c9/AASB116_07-

04_COMPjun14_07-14.pdf>. Consulted 9 October 2015.

Abelson, P. and Joyeux, R. 2015. New development: Smoke and mirrors - fallacies in the New South Wales Government's views on local government financial capacity. Public Money \& Management 35(4): 315-20.

Adelman, J. ed. 2013. The essential Hirschman. Princeton: Princeton University Press.

Aristotle. [350 BCE] 2012. The art of rhetoric. London: Collins Classies.

Baird, M. 2015. Stronger councils for Sydney and regional NSW. Media release, 18 December. Sydney: NSW Government. URL: <https://www.nsw.gov.au/mediareleases-premier/stronger-councils-sydney-and-regional-nsw>. Consulted 21 December 2015.

Brown, M. 2015. More NSW councils in deficit as State Government urges amalgamation. ABC [Australian Broadcasting Corporation] News. 12 June. URL: <http://www.abc.net.au/news/2015-06-12/local-government-report-for-nsw-showsmore-councils-in-the-red/6541940>. Consulted 8 October 2015.

Buckingham-Jones, S. and Robertson, J. 2015. 'State's council's rich and getting richer as merger deadline looms'. Sydney Morning Herald 30 June. URL: <http://www.smh.com.au/nsw/states-councils-rich-and-getting-richer-as-mergerdeadline-looms-20150630-gi18tu.html>. Consulted 6 October 2015.

Burton, T., Dollery, B. and Wallis, J. 2002. A note on the debate over 'Economic Rationalism' in Australia: An application of Albert Hirschman's rhetoric of reaction. History of Economics Review 36: 1-9. 
City of Ryde 2015. Fit for the Future - Joint response from the Councils of Hunter's Hill, Lane Cove and City of Ryde. Ryde: City of Ryde. Available at URL: <http://www.ryde.nsw.gov.au/Council/Fit-for-the-Future\#submission>. Consulted 12 October 2015.

Destination 2036 [Destination 2036 Implementation Steering Committee]. 2012. Destination 2036 - A path together action plan June 2012, URL: 〈https://www.olg.nsw.gov.au/sites/default/files/Destination-2036-Action-Plan.pdf>. Consulted 9 October 2015.

Dollery, B. and Crase, L. 2003. Rhetorical patterns in the Australian debate over war with Iraq. Prometheus: Critical Studies in Innovation, 21(3): 355-63.

Dollery, B. E. and Tiley, I. eds 2015. Perspectives on Australian local government reform. Sydney: Federation Press.

Drew, J., and Dollery, B. 2014. Estimating the impact of the proposed Greater Sydney metropolitan amalgamations on municipal financial sustainability. Public Money \& Management, 34(4): 281-88.

Drew, J., Grant, B. and Fisher, J. (forthcoming). Re-evaluating local government amalgamations: Utility maximisation meets the Principle of Double Effect (PDE). Policy and Politics.

Drew, J., Kortt, M. and Dollery, B. 2015. No Aladdin's Cave in New South Wales? Local government amalgamation, scale economies and data envelopment specification. Administration \& Society DOI: 10.1177/0095399715581045

Finlayson, A. 2004. Political science, political ideas and rhetoric. Economy and Society, $33(4), 528-49$.

Finlayson, A. 2006. What's the problem? Political theory, rhetoric and problem-setting. Critical Review of International Social and Political Philosophy, 9(4): 541-57. 
Foley, L. 2015. Council boundaries drawn up by the Liberal Party for the Liberal Party. Media release, 18 December. Sydney: NSW Labor. URL: $<$ http://www.lukefoley.com.au/council_boundaries_drawn_up_by_the_liberal_party for the liberal_party>. Consulted 18 December 2015.

Grube, D. 2011. Speech cycle? Election defining rhetoric in Westminster democracies. Australian Journal of Political Science, 46(1): 35-52

Hirschman, A. 1991. The rhetoric of reaction: Perversity, futility, jeopardy. Cambridge: Belknap Press of Harvard University Press.

Hirschman, A. 1993. The Rhetoric of Reaction - two years later. Government and opposition 28(3): 292-314.

Hood, C. 1998. The art of the state - culture, rhetoric, and public management. Oxford: Clarendon Press.

Hood, C. 2007. What happens when transparency meets blame-avoidance? Public Management Review 9(2): 191-210.

Hopwood, A. 1987. The archaeology of accounting systems. Accounting, Organisations and Society, 112(3): 207-34.

ILGRP [Independent Local Government Review Panel]. 2012. Better, stronger local government + The case for sustainable change. Sydney: ILGRP. URL: <http://www.localgovernmentreview.nsw.gov.au/documents/LGR/Stage\%200ne\%2 0Consultation\%20-\%20The\%20Case\%20for\%20Change.pdf>. Consulted 9 October 2015.

ILGRP [Independent Local Government Review Panel]. 2013a. Revitalising local government. Final report. October 2013. Sydney: ILGRP. URL: <http://www.localgovernmentreview.nsw.gov.au/documents/LGR/Revitalising\%20L 
ocal\%20Government\%20-\%20ILGRP\%20Final\%20Report\%20-

\%200ctober\%202013.pdf>. Consulted 12 October 2015.

ILGRP [Independent Local Government Review Panel]. 2013b. Future directions for NSW local government. Twenty essential steps. April 2013. Sydney: ILGRP. URL: < $\underline{\text { http://www.localgovernmentreview.nsw.gov.au/documents/LGR/Future\%20Directi }}$ ons\%20Paper.pdf>. Consulted 12 October 2015.

IPART [Independent Pricing and Regulatory Tribunal]. 2015. Methodology for assessment of council Fit For the Future proposals - local government assessment methodology. June $2015 . \quad$ IPART: Sydney. URL: < http://www.ipart.nsw.gov.au/Home/Industries/Local_Govt/Reviews/Fit_for_the_fu ture/Review_of_Local_Council_Fit_For_The_Future_proposals/05_Jun_2015_Final_Report_-

_Fit_for_the_Future_assessment_methodology/Assessment_Methodology__Methodology_for_Assessment_of_Council_Fit_for_the_Future_Proposals_June_2015>. Consulted 12 October 2015.

Jones, A. 2015. Alan Jones - Professor Brian Dollery (radio interview). The Alan Jones Breakfast Show. URL: <http://www.2gb.com/article/alan-jones-professor-briandollery>. Consulted 8 October 2015.

Kane, J. and Patapan, H. 2010. The artless art: Leadership and the limits of democratic rhetoric. Australian Journal of Political Science 45(3): 371-89.

LGI ('Allan Report') [Independent Inquiry into Local Government Inquiry] 2006. Are councils sustainable? Final report: Findings and recommendations. Sydney: NSW Local Government and Shires Association. 
Local Government Act 1993 (New South Wales). URL: 〈http://www.austlii.edu.au/au/legis/nsw/consol_act/lga1993182/>. Consulted 12 October 2015.

McCloskey, D. 1998. The rhetoric of economics. Wisconsin: University of Wisconsin Press. McKenny, L. 2015. Council amalgamation: MPs vow to fight forced amalgamation. The Sydney Morning Herald, 11 June. URL: <http://www.smh.com.au/nsw/councilamalgamation-mps-vow-to-fight-forced-mergers-20150611-ghltvx.html>. Consulted 6 October 2015.

NSW Government. (2014). Report on state finances 2013-14. URL: <http://www.treasury.nsw.gov.au/_data/assets/pdf_file/0020/125183/201314_NSW_Report_on_State_Finances_dnd.pdf>. Consulted 12 October 2015.

OLG [Office of Local Government (New South Wales)]. 2014. Fit for the Future - A blueprint for the future of local government. Sydney: NSW Office of Local Government. URL: <http://www.fitforthefuture.nsw.gov.au/sites/fftf/files/Fit-forthe-Future-A-Blueprint-for-the-future-of-Local-Government.pdf>. Consulted 8 October 2015.

OLG [Office of Local Government (New South Wales)]. 2015a. Local government code of accounting practice and financial reporting (Guidelines) - Update No. 23 June 2015. Sydney: NSW Office of Local Government.URL: <https://www.olg.nsw.gov.au/sites/default/files/Code\%20Update\%2023\%20\%20General\%20Purpose\%20Financial\%20Statements\%20(Guidelines)\%20\%20Fin al\%20Draft\%20.pdf>. Consulted 12 October 2015.

OLG [Office of Local Government (New South Wales)]. 2015b. Ministerial media releases. URL: $\quad$ https://www.olg.nsw.gov.au/our-minister/ministerial-media-releases >. Consulted 12 October 2015. 
PwC [PricewaterhouseCoopers]. 2006. National financial sustainability study of local government - Commissioned by the Australian Local Government Association, November 2006. Sydney: PwC.

Roan, A. and White, C. 2010. A rhetoric of change: The language of the Howard government's 2005 Work Choices agenda. Australian Journal of Political Science 45(3): 337-52.

Save our Councils Coalition. 2015. Submission to: Local Government in New South Wales (Inquiry). Available at URL: < http://www.parliament.nsw.gov.au/prod/parlment/committee.nsf/0/4E8A.01205B70 316CCA257E8800052FC7>. Consulted 6 October 2015.

Shorten, R. 2015. Reactionary rhetoric reconsidered. Journal of Political Ideologies 20(2): 179-200.

Silmalis, L. 2015. You're fired: An end to revolting councils'. In The Sunday Telegraph, 16 August. URL: < $\quad$ http://Www.pressreader.com/australia/the-sunday-telegraphsydney/20150816/>. Consulted 8 October 2015.

State Parliament of NSW [Hansard]. 2014a. Legislative Assembly 10 September 2014 [full transcript].

URL: <https://www.parliament.nsw.gov.au/prod/parlment/hansart.nsf/V3Key/LA2014091

0038>. Consulted 8 October 2015.

State Parliament of NSW [Hansard]. 2014b. Legislative Assembly 11 September 2014 [full transcript] URL: <https://www.parliament.nsw.gov.au/prod/parlment/hanstrans.nsf/V3ByKey/LA201 40911/\$File/LA20140911.pdf>. Consulted 8 October 2015.

State Parliament of NSW [Hansard] 2015a. Legislative Assembly Parliamentary Debate 14 May 2015. Local government amalgamations. [Hansard extract]. URL: 
<http://www.lgnsw.org.au/files/imce-uploads/127/lg-amalgamations-parliamentarydebate-extract-14.5.15.pdf>. Consulted 8 October 2015.

State Parliament of NSW [Hansard]. 2015b. Legislative Assembly Parliamentary Debate 2 June. Local government amalgamations [full transcript]. URL: <https://www.parliament.nsw.gov.au/Prod/parlment/hanstrans.nsf/V3ByKey/LA201 50602/\$File/LA20150602.pdf>. Consulted 8 October 2015.

State Parliament of NSW [Hansard] 2015c. Legislative Assembly Parliamentary Debate 3 June [full transcript]. URL: <http://www.parliament.nsw.gov.au/prod/parlment/hanstrans.nsf/V3ByKey/LC2015 0603/\$File/LC20150603.pdf>. Consulted 8 October 2015.

Ten (Television) News. 2015. Councils to fight forced mergers. URL: <http://tenplay.com.au/news/sydney/2015/7/27/councils-to-fight-forced-mergers $>$. Consulted 8 October 2015.

Toole, P. 2015. Report card shows majority of councils still operating in the red. Media release, 16 June. Sydney: Minister for Local Government. URL: <https://www.olg.nsw.gov.au/news/report-card-shows-majority-councils-stilloperating-red >. Consulted 12 October 2015.

USU [United Services Union]. 2015. Local government reform: Submission to IPART. URL: <http://www.usu.org.au/news/local-government/1192-local-government-reform-ususubmission-to-ipart>. Consulted 12 October 2015.

Wallis, J. and Dollery, B. 1999. Market failure, government failure, leadership and public policy. London: Macmillan.

Walter, R, and Uhr, J. 2013. Budget talk: Rhetorical constraints and contests. Australian Journal of Political Science 48(4): 431-44. 